\section{ABO BLOOD GROUPS AND SEX RATIO AT BIRTH}

\author{
BY
}

T. M. ALLAN, M.B., Ch.B.

Blood Transfusion Centre, Royal Infirmary, Aberdeen

\begin{abstract}
"Though I have very little evidence on this head. analogy would lead one to the belief that the tendency to produce either sex would be inherited."-Darwin, The Descent of Man and Selection in Relation to Sex.
\end{abstract}

\section{Sex Ratio at Birth according to the ABO Blood Group of Mothers}

In 1925 Hirszfeld and Zborowski pointed out that in their series of 264 white newborn baby-mother combinations the sex ratio-that is, the ratio of males to females-was very much higher for the babies of $A B$ mothers than for the rest-namely, $2.87(23: 8)$ compared with $1.04(119: 114)$-and they declared that "if this finding were confirmed it would have far-reaching theoretical significance." (Italics mine.) The finding, however, at once fell into oblivion, and it did not appear in any of the invaluable scholarly source-books of Snyder (1929), Lattes (1929), Steffan (1932), and Wiener (1935), or in any of the extensive surveys of early blood group findings by Levine (1928), Witebsky (1932), and Holzer (1935). On its eventual re-emergence Allan (1955) showed that the finding was not confirmed in the aggregate of all the other series of white newborn babies reported in 1924-54, and the same proved true of Cohen and Glass's (1956) large series. In both of the latest (and much the biggest) series, however-namely, the first 5,612 cases of Allan (1958) and the first 15,475 cases of Shield et al. (1958), the latter especially-the sex ratio is much the highest for the babies of $\mathrm{AB}$ mothers, while in the aggregate of all the 1924-58 white series the sex ratio of the babies of $A B$ mothers is significantly higher than that of the rest-namely, $1.26(667: 531)$ compared with $1.08(16,130: 14,982)$. The $1924-56$ and 1958 aggregates are shown in Table I.

TABLE I.-Sex Ratio of White Newborn Babies

\begin{tabular}{|c|c|c|c|c|c|c|c|}
\hline \multicolumn{4}{|c|}{ 1924-56 White Series } & \multicolumn{4}{|c|}{1958 White Series } \\
\hline $\begin{array}{l}\text { Mothers' } \\
\text { Group }\end{array}$ & $\begin{array}{c}\text { Male } \\
\text { Babies }\end{array}$ & $\begin{array}{c}\text { Female } \\
\text { Babies }\end{array}$ & $\begin{array}{c}\text { M./F. } \\
\text { Babies }\end{array}$ & \begin{tabular}{|c} 
Mothers' \\
Group
\end{tabular} & $\begin{array}{c}\text { Male } \\
\text { Babies }\end{array}$ & $\begin{array}{l}\text { Female } \\
\text { Babies }\end{array}$ & $\begin{array}{l}\text { M./F. } \\
\text { Babies }\end{array}$ \\
\hline $\begin{array}{l}\mathrm{AB} \\
\mathrm{O} \\
\mathrm{A}\end{array}$ & $\begin{array}{r}257 \\
2,435 \\
2,296\end{array}$ & $\begin{array}{r}229 \\
2,356 \\
2,279\end{array}$ & $\begin{array}{l}1.12 \\
1.03 \\
1.01\end{array}$ & $\begin{array}{l}\mathrm{AB} \\
\mathrm{O} \\
\mathrm{A}\end{array}$ & $\begin{array}{r}410 \\
5,231 \\
4,299\end{array}$ & $\begin{array}{r}302 \\
4,709 \\
3,898\end{array}$ & $\begin{array}{l}1.36 \\
1 \cdot 11 \\
1 \cdot 10\end{array}$ \\
\hline B & 732 & 639 & $1 \cdot 15$ & B & 1,137 & 1,101 & 1.03 \\
\hline
\end{tabular}

Non-white Series.-In the aggregate of the only two non-white series reported so far-those of Sanghvi (1951) and of Cohen and Glass (1956)-the sex ratio of the babies of $A B$ mothers is $1.30(78: 60)$, while that of the rest is $1.10(1,129: 1,024)$.

\section{Sex Ratio at Birth when Mothers and Babies' ABO Groups are the Same}

As a result of the oblivion into which Hirszfeld and Zborowski's 1925 observation immediately fell, more than a quarter of a century elapsed before the subject as a whole was brought to life again - " the years that the locust has eaten," as Fraser Roberts (1957) has described the three decades between the papers of Buchanan and Higley (1921) and Aird et al. (1953) on the blood groups and disease. This renascence came in 1951, with Sanghvi's finding that in both his series the sex ratio of the $O$ babies of $O$ mothers was significantly higher than that of the A babies of A mothers, and it is notable that a trend in the same direction, to a greater or less degree, is found in each of the individual 1924-58 series, including Dossena's (1924), apart from the five small early white series shown in italics in Table II (cf. Edwards, 1957). Indeed, in the aggregate of all the 1924-58 white series the sex ratio of the $O$ babies of $O$ mothers is very significantly higher than that of the $\boldsymbol{A}$ babies of $A$ mothers - namely, $1.11 \quad(5,335: 4,806)$ compared with $1.02(4,054: 3,972)$.

\begin{tabular}{|c|c|c|c|c|c|}
\hline \multicolumn{3}{|c|}{ Series in Order of Publication } & $\begin{array}{l}\text { Total No. } \\
\text { of Babies }\end{array}$ & $\begin{array}{l}\text { O Babies of } \\
\text { O Mothers }\end{array}$ & $\begin{array}{l}\text { A Babies of } \\
\text { A Mothers }\end{array}$ \\
\hline 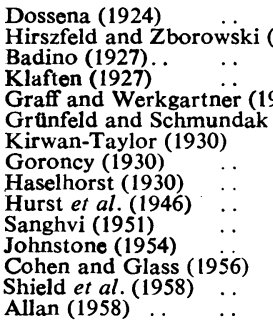 & $\begin{array}{l}1925) \\
\ldots \\
28) \\
(1928) \\
\ldots \\
\ldots \\
\ldots \\
\ldots \\
\ldots \\
\ldots \\
\ldots \\
\ldots\end{array}$ & $\begin{array}{l}\cdots \\
\cdots \\
\cdots \\
\cdots \\
\cdots \\
\cdots \\
\cdots \\
\cdots \\
\cdots \\
\cdots \\
\cdots \\
\cdots \\
\cdots\end{array}$ & $\begin{array}{r}148 \\
264 \\
200 \\
200 \\
494 \\
168 \\
250 \\
285 \\
2,331 \\
181 \\
864 \\
2,429 \\
3,577 \\
15,475 \\
5,612\end{array}$ & $\begin{array}{l}1.09 \\
0.84 \\
0.92 \\
0.67 \\
0.91 \\
2.37 \\
1.05 \\
1.09 \\
1.07 \\
1.07 \\
1.29 \\
1.04 \\
1.03 \\
1.16 \\
1.09\end{array}$ & $\begin{array}{l}0.60 \\
1.15 \\
2.33 \\
0.90 \\
1.03 \\
1.20 \\
1.17 \\
0.76 \\
0.96 \\
0.65 \\
0.84 \\
1.00 \\
0.93 \\
1.07 \\
1.00\end{array}$ \\
\hline $\begin{array}{l}\text { Sanghvi* (1951) } \\
\text { Cohen and Glass (1956)* }\end{array}$ & $\begin{array}{l}\cdots \\
\cdots\end{array}$ & $\begin{array}{l}\cdots \\
\cdots\end{array}$ & $\begin{array}{r}1,330 \\
961\end{array}$ & $\begin{array}{l}1 \cdot 53 \\
1 \cdot 14\end{array}$ & $\begin{array}{l}0.99 \\
0.74\end{array}$ \\
\hline
\end{tabular}

Non-white Series. - In the aggregate of the two nonwhite series the sex ratio of the $O$ babies of $O$ mothers is $1.30(332: 255)$, while that of the $\mathrm{A}$ babies of $A$ mothers is $0.87(183: 210)$, the difference being significant.

\section{Sex Ratio at Birth according to the ABO Blood Group of Babies}

In the aggregate of the 1924-54 white series (Allan, 1955) the descending order of sex ratios of the babies was shown to be B babies-O babies-A babies, especially where the babies were of the same group as their mothers. This $\mathrm{B}-\mathrm{O}-\mathrm{A}$ descending order appeared yet again in Cohen and Glass's (1956) large series, while in particular the sex ratio of the B babies is, in the 1924-56 aggregate, significantly higher than that of the $O$ babies. In both of the large 1958 series, however, the sex ratio of the B babies is lower than that of the $\mathrm{O}$ babies, and if this were confirmed the significantly high sex ratio of the 1924-56 B babies might be thought to have arisen from one or other of at least three possible causes. These are: (1) chance variation; (2) some change, however caused, in the selective characteristics of the $B$ gene ; and (3) provided the high sex ratio of the $1958 \mathrm{AB}$ babies were also confirmed, the systematic tendency for $\mathrm{A}_{2} \mathrm{~B}$ individuals, babies especially, to be included among the B's. (The last is a very unlikely cause, owing to the smallness of the number of $A_{2} B$ compared with $B$ babies.) Meantime it may be noted that in the aggregate of all the 1924-58 white series the sex ratio of the $O$ babies

TABLE III.-Sex Ratio of White Newborn Babies, 1924-58

\begin{tabular}{|c|c|c|c|c|c|c|c|}
\hline \multicolumn{4}{|c|}{ 1924-56 White Series } & \multicolumn{4}{|c|}{1958 White Series } \\
\hline $\begin{array}{l}\text { Babies' } \\
\text { Group }\end{array}$ & $\begin{array}{c}\text { Male } \\
\text { Babies }\end{array}$ & $\begin{array}{l}\text { Female } \\
\text { Babies }\end{array}$ & $\begin{array}{l}\text { M./F. } \\
\text { Babies }\end{array}$ & $\begin{array}{l}\text { Babies' } \\
\text { Group }\end{array}$ & $\begin{array}{c}\text { Male } \\
\text { Babies }\end{array}$ & $\begin{array}{l}\text { Female } \\
\text { Babies }\end{array}$ & $\begin{array}{l}\text { M. } / F \text {. } \\
\text { Babies }\end{array}$ \\
\hline B & 786 & 656 & 1.20 & B & 1,170 & 1,069 & 1.09 \\
\hline $\begin{array}{l}\mathbf{A B} \\
\mathbf{O} \\
\mathbf{A}\end{array}$ & $\begin{array}{r}211 \\
2,483 \\
2,240\end{array}$ & $\begin{array}{r}199 \\
2,367 \\
2,281\end{array}$ & $\begin{array}{l}1.06 \\
1.05 \\
0.98\end{array}$ & $\begin{array}{l}\mathbf{A B} \\
\mathbf{O} \\
\mathbf{A}\end{array}$ & $\begin{array}{r}357 \\
5,431 \\
4,119\end{array}$ & $\begin{array}{r}283 \\
4,781 \\
3,877\end{array}$ & $\begin{array}{l}1.26 \\
1.14 \\
1.06\end{array}$ \\
\hline
\end{tabular}


as a whole is very significantly higher than that of the $A$ babies as $a$ whole-namely, $1.11(7,914: 7,148)$ compared with $1.03(6,359: 6,158)$. It is also worthy of note that there is a very significant shortage of $\mathrm{A}$ male babies compared with A mothers of male babiesnamely, 6,359 compared with 6,595. The 1924-56 and 1958 white aggregates are shown in Table III.

Non-white Series.-In the aggregate of the two nonwhite series the sex ratio of the $O$ babies as a whole is $1.20(499: 416)$, while that of the $A$ babies as a whole is $0.93(332: 356)-a$ non-significant difference. Here, however, there are $332 \mathrm{~A}$ male babies compared with 326 A mothers of male babies.

\section{Statistical Note by W. Brass}

For all four ABO blood groups combined the sex ratios do not differ significantly as between individual series, and aggregation does not introduce any appreciable bias. It also seems fair to assume that the method of selection of babies did not introduce any dependence of sex on blood group. Thus the significance of differences in sex ratios has been tested by simple contingency table procedures. Three small white series with incomplete data-those of Koller (1926), Grünfeld and Schmundak (1928), and Wolff and Jonsson (1935) - have been excluded from all the totals.

\section{Conclusion}

All known series of blood-grouped newborn babies and their parents are combined and analysed in respect of sex ratio, and three main observations are made. (1) In accordance with Hirszfeld and Zborowski's finding, the sex ratio of the babies of white group $A B$ mothers is, in the aggregate, significantly higher than that of the babies of $\mathrm{O}, \mathrm{A}$, and $\mathrm{B}$ mothers combined. (2) In accordance with Sanghvi's finding, the sex ratio of the white $\mathrm{O}$ babies of $\mathrm{O}$ mothers is, in the aggregate, very significantly higher than that of the A babies of A mothers. (3) The sex ratio of the white $O$ babies as a whole is, in the aggregate, very significantly higher than that of the A babies as a whole. From these observations it may be concluded that the existence of blood-group differences in the human sex ratio at birth is now a very strong probability, at any rate in the white races.

\section{APPENDIX}

\section{Sex Ratio at Birth According to the ABO} Blood Group of Fathers

In 1954 Johnstone noted that in his white series of 2,141 baby-father-mother combinations the sex ratio of the babies of B fathers was much lower than that of the babies of $B$ mothers. In view of this it is notable that in the aggregate of all seven white series of newborn baby-father combinations-the other six are those of Dossena (1924), Klaften (1927), Graff and Werkgartner (1928), Kirwan-Taylor (1930), Haselhorst (1930), and Cohen and Glass (1956)-the sex ratios are, in descending order, $1.22(144: 118)$ for babies of $A B$ fathers, $1.09(1,545: 1,423)$ for babies of $O$ fathers, 1.02 $(1,506: 1,472)$ for babies of $A$ fathers, and only 0.95 (562:594) for babies of $B$ fathers. None of these intergroup differences, however, is significant.

My own series is part of a research programme supported by a grant from the Scottish Hospital Endowments Research Trust and the Scottish National Blood Transfusion Association, to whom my grateful thanks are expressed. I am grateful to Professor John Cruickshank and Dr. J. S.
Campbell, respectively the past and present Regional Directors of the North-east Scotland Blood Transfusion Service, for much encouragement and help; to Professor Dugald Baird and the nursing and secretarial staff of the Aberdeen Maternity Hospital and its associated nursing homes for their kind co-operation ; to Mr. Alfred Johnston and Mrs. Rosaleen Noble for their conscientious technica! and secretarial work; and to Mr. William Brass for his statistical analysis of the data, and for much very helpful comment.

\section{REFERENCES}

Aird, I., Bentall, H. H., and Roberts, J. A. F. (1953), Brit. med. J., 1,799

Allan, T. M. (1955). Lancet, $2,94$.

(1958). Brit. med. J., 2, 248.

Badino, P (1927). Riv. ital. Ginec., 6, 656.

Buchanau, J. A., and Higley, E. T. (1921). Brit. J. exp. Path., 2, 247.

Cohen, B. H. and Glass, B. (1956). Hum. Biol., 28, 20

Dossena, G. (1924). Ann. Ostet. Ginec., 46, 335.

Edwards, J. H. (1957). Brit. J. prev. soc. Med., 11, 79.

Goroncy, C. (1930). Z. Geburtsh. Gynäk., 97, 30.

Graff. E., and Werkgartner, A. (1928). Beitr. gerichtl. Med., 7, 98. Grünfeld, W., and Schmundak, D. (1928). Ukr. Zbl. Blutgr., 3, 154.

Haselhorst, G. (1930). Z. KonstLehre, 15, 177.

Hirszfeld, L., and Zborowski, H. (1925). Klin. Wschr., 4, 1152 Holzer, F. J.' (1935). Ergebn. ges. Med., 20, 367.

Hurst, J. G., Taylor, H. C., and Wiener, A. S. (1946). Blood, 1 , 234.

Johnstone, J. M. (1954). Erit. J. prev. soc. Med., 8, 124

Kirwan-Taylor, G. K. (1930). J. Path. Bact., 33, 313

Klaften, E. (1927). Mschr. Geburtsh. Gynäk., 76, 91

Koller, T. (1926). Arch Klaus-Stift. VerebForsch., 2, 247.

Lattes, L. (1929). L'Individualité du Sang. Masson, Paris.

Levine, P. (1928). Ergebn. inn. Med. Kinderheilk., 34, 111.

Roberts, J. A. F. (1957). Brit. J prev. soc. Med., 11, 107.

Sanghvi, L. D. (1951). Nature (Lond.), 168, 1077.

Shield, J. W., Kirk, R. L., and Jakobowicz, R. (1958). Amer. J. hum Genet., 10, 154.

Snyder, L. H. (1929). Blood Grouping in Relation to Clinical and Legal Medicine. Baillière, Tindall and Cox, London.

Steffan P. (1932). Handbuch der Blutgruppenkunde. Lehmann, Munich.

Wiener, A. S. (1935). Blood Groups and Blood Transfusion. Thomas, Springfield, III.

Witebsky, E. (1932). Ergebn. Physiol., 34, 271-359.

Wolff. E., and Jonsson, B. (1935). Acta path. microbiol. scand., 12, 131 .

\section{SPONTANEOUS THROMBOSIS OF THE EXTERNAL CAROTID ARTERY}

BY

\section{JACK DOMINIAN, M.B., M.R.C.P.Ed.}

Senior House Officer, Department of Neurology, United Oxford Hospitals

AND

JOHN LOWE, M.D., F.R.C.S.Ed.

Consultant Physician, Swindon and District Hospitals

With the modern widespread use of angiography, thrombosis of the carotid artery tree has been increasingly reported in recent years (Johnson and Walker, 1951 ; Webster, Gurdjian, and Martin, 1956). This interest has been further augmented by the intervention of surgery in the prevention and reversal of some of the disastrous neurological effects (Eastcott, Pickering, and Rob, 1954 ; Edwards and Rob, 1956 ; Hamlin, Sweet, and Lougheed, 1958). All these cases deal with thrombosis of the common carotid and internal carotid arteries. We report here a case of spontaneous thrombosis of the external carotid artery.

\section{Case Report}

A man aged 65, a gatekeeper with British Railways, experienced a sudden severe pain on the right side of his head which came on within seconds and lasted with 